\title{
PENGARUH PENGGUNAAN MEDIA SOSIAL FACEBOOK TERHADAP HASIL BELAJAR PESERTA DIDIK MATA PELAJARAN PENDIDIKAN AGAMA ISLAM (PAI)
}

\author{
Moh Saeful Ulum, Muhammad Al Ghiffarie Tsaronny \\ Institut Agama Islam Cipasung Tasikmalaya \\ syaefululum@rocketmail.com ghiffarie165@gmail.com
}

\begin{abstract}
Abstrack
This study aims to determine the influence of the use of facebook toward student learning outcomes on Islamic Education at SDN 3 Tanjungkerta. The method used in this study is a quantitative descriptive method, because the data or research sample are both normal distribution variables, then the correlation coefficient uses the Spearman rank (rs) or rank. The results of this study for variable $X$ (Facebook usage) are the degree of determination is 53.39\%, while $46.61 \%$ is influenced by other factors. The results of the significance test or hypothesis test show that tcount (4.71) is greater than ttable, (1.72) so that Ha (Alternative Hypothesis) is accepted and HO (Zero Hypothesis) is rejected. It means that the influence of using facebook toward student learning outcome is very high enough.
\end{abstract}

Keywords: Facebook, Learning Outcomes, Islamic Education

\begin{abstract}
Abstrak
Penelitian ini bertujuan untuk mengetahui pengaruh penggunaan media social facebook terhadap hasil belajar peserta didik mata pelajaran Pendidikan Agama Islam di SDN 3 Tanjungkerta. Metode yang digunakan dalam penelitian ini adalah metode deskriptif kuantitatif, Dikarenakan data atau sampel penelitian kedua variabel distribusi normal dan koefisien korelasinya menggunakan rank spearman (rs) atau peringkat. Hasil penelitian menunjukkan bahwa Derajat determinasi adalah 53,39 \%, sedangkan 46,61 \% dipengaruhi faktor lain. Hasil uji signifikasi atau uji hipotesis menunjukkan bahwa $t_{\text {hitung }}(4,71)$ lebih besar dari pada $t_{\text {tabel}},(1,72)$ sehingga $\mathrm{Ha}$ (Hipotesis Alternatif) di terima dan $\mathrm{HO}$ (Hipotesis Nol) ditolak. Artinya bahwa pengaruh penggunaan facebook terhadap hasil belajar mata pelajaran PAI tergolong cukup tinggi.
\end{abstract}

Kata kunci: Facebook, Hasil Belajar, Pendidikan Agama Islam 


\section{A. PENDAHULUAN}

Di era globalisasi media sosial menjadi alat komunikasi yang banyak menyita waktu dalam dalam kehidupan sehari-hari. Hal tersebut ditandai dengan banyaknya pengguna sosial media atau akun media sosial dari mulai usia dini sampai orang tua. Fenomena ini sangat unik karena memasuki era digital dimana semua komunikasi dilakukan melalui sosial media, tanpa harus bertemu langsung face-to face. Apalagi Indonesia memasuki revolusi industry 4.0. Artinya bahwa seluruh rakyat Indonesia akan memebiasakan dengan digital dan system. Rakyat Indonesia harus sadar akan pentingnya terutama memebekali generasi muda sejak dini dengan kemampuan digital.Walaupun demikian ilmu agama islam yang aplikatif juga sangat penting menjadi dasar dan filter serta ruh dari kehidupan.

Secara umum penggunaan media sosial tentunya memiliki dampak positif dan negatif tergantung dari usernya (Faoz, 2014:31). Dampak positif medsos antara lain, melatih keterampilan dan menambah pengetahuan dan update berita terbaru. Namun menurut pakar pendidikan anak Kak Seto dalam seminar di Tasikmalaya 23 November 2018, menyatakan bahwa penggunaan media sosial bagi anak dinilai lebih banyak memiliki dampak negatif dari pada positif. Hal ini disebabkan oleh manfaat media sosial yang kurang maksimal, sehingga anak menjadi terlena untuk berkomunikasi secara bebas dengan teman sebaya atau tidak sebaya. Hal ini jelas sangat mempengaruhi sikap dan cara berfikir anak. Selain itu penggunaan media sosial bagi anak seringkali disalahgunakan untuk mencari kesenangan mencari teman tanpa ada selektif, yang berkibat seperti viral dalam pemberitaan terbaru di televisi bahwa seorang anak perempuan menjadi korban pelecehan seksual oleh pemuda yang menagajak bertemu melalui pesan facebook. Hal ini tentunya menjadi keprihatinan para orang tua dan guru untuk selalu mengawasi dan membimbing penggunaan media sosial bagi anak. Dampak lainnya adalah anak menjadi malas belajar karena mereka terlena dan enjoyable dengan fitur yang ada dalam media sosial, seperti upload foto atau video, membuat status, dan chatting. Mereka juga gagal fokus materi pelajaran di sekolah karena kecanduan untuk selalu 
Moh Saeful Ulum, Muhammad Al Ghiffarie Tsaronny I Pengaruh Penggunaan Media...

membuka pesan chatting dan membaca informasi di media sosial (Pardosi: 2013, 2).

Fenomena di atas terjadi pada siswa SDN 3 Tanjungkerta kelas VI, dimana mereka setiap hari membawa alat komunikasi HP dan menggunakan media sosial di sekolah. Hal ini diperbolehkan oleh pihak sekolah dengan alasan membantu siswa untuk searching informasi dan pengetahuan terbaru. Tentunya siswa kelas VI menjadi semakin bebas untuk berekpresi di dunia maya. Selain itu peran guru kelas harus lebih maksial dalam mengawasi anak.

Siswa kelas VI sudah tidak gaptek (gagap teknologi) terlebih pemerintah mengantisipasi era distruptif. Dustruptif era terjadi kepada masyarakat yang tidak ingin berubah sesuai dengan perkembangan teknologi terbaru (Kasali: 2018). Artinya bahwa setiap warga Negara harus terbiasa dengan program, informasi dan aplikasi serba digital, termasuk media sosial. Jika mereka tidak menyesuasikan dengan system digital, maka mereka akan tergilas oleh waktu dan situasi. Mereka menggunakan medsos dengan lancar dan cepat. Media sosial yanga paling banyak digunakan oleh anak-anak kelas VI di SDN 3 Tanjungkerta adalah facebook, whatsapp dan instagram. Ketiga media ini sering sebagai alat untuk alat komunikasi dan bahan pembelajaran bagi siswa. Facebook menjadi paling favorit sebagai media sosial yang banyak diminati dan digunakan oleh anak SDN 3 Tanjungkerta karena berisi konten yang sangat lengkap dan memberikan ruang khusus untuk mengekspresikan kesenangan anak-anak. Dalam facebook terdapat fitur chatting, upload gambar atau video, status dan game.

Walaupun dampak negatif lebih besar dari pada positifnya, siswa kelas VI mampu mempertahankan hasil belajar pendidikan agama Islam mereka sesuai dengan standart KKM. Penggunaan media social tentunya menyita perhatian dan kehilangan fokus belajar, namun jika penggunaan media sosial dalam bimbingan orang tua dan guru, maka akan berakibat positif terhadap manfaat medsos untuk anak. Hal ini menjadi sebuah asumsi bahwa penggunaan media sosial oleh siswa kelas VI diduga memberikan sebuah dampak baik bagi mereka. Padahal dampak negatif dari penggunaan medsos adalah anak menjadi malas dan menurunkan etika sosial anak. Indikator pembelajaran PAI antara lain 
hafalan dan akhlak kepada manusia, kepada Tuhan dan kepada lingkungan. Tujuan Penelitian sesuai dengan rumusan masalah di atas, tujuan dari penelitian ini sebagai berikut, untuk mengetahui penggunaan facebook di SDN 3 Tanjungkerta pada mata pelajaran PAI, untuk mengetahui hasil belajar mata pelajaran PAI di SDN 3 Tanjungkerta, untuk mengetahui pengaruh penggunaan facebook terhadap hasil belajar peserta didik pada mata pelajaran PAI di SDN 3 Tanjungkerta.

\section{Kerangka Pemikiran dan Paradigma Penelitian}

Penggunaan facebook menjadi salah satu alat komunikasi yang penting disamping media sosial lainnya bagi anak-anak. Anak anak memiliki akun facebook untuk berinteraksi melalui chatting mengirim gambar dan upload status dan foto. Hal ini tentunya membawa dampak negative terhadap fisik dan mental anak, terlebih terhadap hasil belajar pendidikan agama Islam di sekolah.

Penggunaan facebook oleh anak tanpa bimbingan orang tua dan guru dapat menyebabkan anak menjadi malas, lupa waktu, dan pasif dalam berinteraksi sosial. Sebaliknya prilaku di atas seharusnya dihindarkan dari kehidupan anak sejak dini. Hal yang lebih fatal lagi jika anak sudah kecanduan media sosial facebook. Tentunya akan lebih berbahaya lagi dan sulit untuk merubah dan menyadarkan kepada jalan yang benar.

Menurut Gen dalam Chairun Nisa (2010:39) menjelaskan ada 8 hal pokok dampak negative dari penggunaan media sosial facebook adalah :

Pertama, Tidak peduli dengan sekitarnya. Orang yang sudah "kecanduan" facebook terlalu "asyik" dengan dunianya sendiri (dunia yang diciptakannya) sehingga tidak peduli dengan orang lain dan lingkungan di sekitarnya. Seseorang yang telah ,kecanduan facebook sering mengalami hal ini, dunianya berubah menjadi dunia facebook. Kedua, Kurangnya sosialisasi dengan lingkungan. Ini dampak dari terlalu sering dan terlalu lama bermain facebook. Ini cukup mengkhawatirkan bagi perkembangan kehidupan sosial anak tersebut. Mereka yang seharusnya masa belajar sosialisasi dengan lingkungan justru lebih banyak menghabiskan waktu lebih banyak di dunia maya bersama teman-teman facebook-nya yang rata-rata membahas sesuatu 
yang tidak penting. Akibatnya, kemampuan verbal siswa SDN 3 Tanjungkerta menurun. Ketiga, Pemborosan uang. Akses internet untuk membuka facebook jelas berpengaruh terhadap kondisi keuangan. Dan biaya internet di Indonesia yang cenderung masih mahal bila dibanding negara negara lain. Keempat, Mengganggu kesehatan. Terlalu banyak duduk di depan monitor tanpa melakukan kegiatan apapun, tidak pernah olah raga sangat beresiko bagi kesehatan. Penyakit akan mudah datang, terlambat makan dan tidur tidak teratur. Kelima, Berkurangnya waktu belajar. Terlalu lama bermain facebook akan mengurangi jatah waktu belajar siswa SD sebagai pelajar. Bahkan ada beberapa yang masih "asyik" bermain facebook saat di sekolah atau di rumah. Ketujuh, Kurangnya perhatian untuk keluarga. Keluarga di rumah adalah nomor satu. Slogan tersebut tidak lagi berlaku bagi para pengguna facebook. Kedelapan, Penipuan. Seperti media media lainnya, facebook juga rawan terhadap penipuan.

Apalagi bagi anak-anak SD yang kurang mengerti tentang selukbeluk dunia internet. Hal ini tentu menjadi sarang yang empuk untuk penipuan, apalagi kondisi dunia maya yang serba anonim jelas sangat menguntungkan.

Walaupun demikian facebook juga memiliki dampak possitif untuk anak di sekolah. Menurut teori Jallei (2009) mengatakan bahwa ada 6 dampak positif dari penggunaan facebook antara lain;
a. Update informasi terkini
b. Berbagi ilmu pengetahuan
c. Tempat curhat
d. Menyimpan dokumen pribadi
e. Media promosi

Hasil belajar merupakan ukuran untuk mengetahui kemampuan penguasaan materi dalah hal ini pendidikan agama Islam. Dampak negatif penggunaan facebook tidak telihat dalam proses dan hasil belajar siswa di SDN 3 Tanjungkerta. Terbukti bahwa nilai hasil belajar siswasiswa masih stabil dan tidak menurun. Artinya bahwa pengaruh pengggunaan facebook cenderung sangat kecil terhadap hasil belajar siswa pada mata pelajaran Pendidikan Agama Islam. Pendidikan agama merupakan pondasi awal dalam menanamkan moral dan karakter 
melalui ritual nilai-nilai Islam, sehingga siswa mampu mengendalikan diri untuk bertakwa kepada Allah SWT., berprilaku karimah terhadap manusia dan lingkungan. Hal ini dapat dilustrasikan dalam paradigma penelitian sebagai berikut.

\section{MEDIA SOSIAL FACEBOOK}

\section{(a) Pengertian Media Sosial}

Media sosial adalah sebuah media online, dengan para penggunanya bisa dengan mudah berpartisipasi, berbagi, dan menciptakan isi meliputi blog, jejaring sosial, wiki, forum dan dunia virtual. Blog, jejaring sosial dan wiki merupakan bentuk media sosial yang paling umum digunakan oleh masyarakat di seluruh dunia. Pendapat lain mengatakan bahwa media sosial adalah media online yang mendukung interaksi sosial dan media sosial menggunakan teknologi berbasis web yang mengubah komunikasi menjadi dialog interaktif. Andreas Kaplan dan Michael Haenlein mendefinisikan media sosial sebagai "sebuah kelompok aplikasi berbasis internet yang membangun di atas dasar ideologi dan teknologi Web 2.0, dan yang memungkinkan penciptaan dan pertukaran user-generated content".

(b) Media social Facebook

Media Sosial merupakan salah satu media internet yang hampir semua kalangan menggunakannya. "Social network sites (SNSs), such as Facebook, are one of the fastest-growing types of websites on the Internet", yang diartikan bahwa sosial media seperti Facebook adalah salah satu media sosial tercepat pertumbuhannya dalam Internet Facebook diluncurkan pertama kali pada tanggal 4 Februari 2006 oleh seorang mahasiswa Harvard University, Mark Zuckerberg. Nama Facebook sendiri diinspirasi oleh Zuckerberg dari sebuah istilah di kalangan kampus Seantero AS untuk saling mengenal antar sesama civitas akademiknya. Awalnya para penggunanya hanya dikhususkan bagi para mahasiswa di kampus Harvard University. Lalu kemudian diperluas ke sejumlah kampus di wilayah Boston 
(Boston College, Boston University, Northeastern University, Tufts University) dan kampus-kampus lainnya seperti Rochester, Stanford, NYU, Northwestern, and Ivy League. Menyusul kemudian sejumlah kampus lain di AS. Akhirnya, penggunanya lebih diperluas lagi ke sejumlah kampus lain di seluruh dunia. Tanggal 11 September 2006, Facebook membuat satu langkah penting dengan mengizinkan aksesnya ke seluruh netter yang mempunyai alamat email valid, namun, dengan pembatasan usia. Pengguna dapat memilih untuk bergabung dengan satu atau lebih jaringan yang tersedia, seperti berdasarkan sekolah tingkat atas, tempat kerja, atau wilayah geografis.

Facebook menjadi kebutuhan pokok dalam kehidupan harihari bagi kaum milenial. Banyaknya pengguna facebook menunjukkan bahwa facebook sangat memberikan ruang untuk berekspresi dengan chatting, mengupload status, video dan foto dan bermain game. Selanjutnya pengguna facebook juga senang membaca informasi terbaru status orang lain. Tentunya menambah penasaran untuk terus berexplorasi dalam fitur facebook.

(c) Dampak Positif dan Negatif Penggunaan Facebook

Facebook sebagai media social yang paling banyak dipakai oleh masyarakat Indonesia dari anak-anak samapi orang tua. Facebook juga memiliki daya magnet yang kuat terhadap prilaku manusia yang memasuki era teknologi. Tentunya konten dari facebook memiliki daya tarik yang sangat besar terhadap pasion dan eksistensi masyarakat saat ini. Aktifitas penggunaan facebook tentunya memiliki dampak positif dan negatif terhadap aktifitas yang dilakukkan sehari-hari. Berikut damapk positif dan negative penggunaan facebook, antar lain;

1) Bisa bertemu dengan saudara yang jauh, bertemu teman lama, maupun rekan kerja.

2) Membagikan informasi terkini. Kita sering melihat status dari pengguna facebook yang sering memberikan inforrmasi di suatu daerah. Sehingga kita bisa tahu peristiwa apa yang sedang terjadi di daerah lain. 
3) Berbagi dan mendapatkan ilmu. Kita bisa mengikuti komunita atau grup yang ada di Facebook. Ada banyak grup di sana namun kita harus pandai memilih grup yang bisa memberi manfaat untuk kita.

4) Anda pasti sering melihat status yang berisikan informasi tentang suatu produk biasanya akan disertai dengan gambar dan informasi lainnya.

Sedangkan dampak negatif dari facebook antara lain;

1. Facebook dijadikan tempat untuk menebarkan kebencian, fitnah, provokasi dll. Banyak orang tidak bijak dalam menggunakan Facebook, mereka sering membuat status yang hanya membuat orang lain terluka dan sakit hati bahkan untuk kelompok tertentu. Status yang biasa dibuat adalah status yang berbau SARA.

2. Adanya kasus penipuan. Tentu anda sering melihat di berita baik di media cetak maupun media elektronik tentang kasus penipuan dengan menggunakan media sosial Facebook.

3. Sering membuang waktu untuk membaca informasi yang tidak penting yang ada di Facebook. Hal ini akan membuat kita malas dan enggan melakukan hal yang lebih bermanfaat.

4. Pengaruh terhadap perkembangan psikologis. Bukan tidak mungkin karakter seseorang terbentuk dari Facebook. Hal ini karena pengguna Facebook menemukan ribuan orang yang memiliki karakter yang berbeda-beda walaupun mereka tidak saling bertemu. Biasanya akan tampak pada status yang dibuatnya.

\section{Hasil Belajar}

\section{Pengertian Hasil Belajar}

Sebagaimana yang di katakan oleh Nana Sudjana (2009:3) bahwa:

Inti dari penilaian adalah proses memberikan atau menentukan nilai kepada objek tertentu berdasarkan suatu kriteria tertentu. Proses pemberian nilai tersebut berlangsung dalam bentuk interpretasi yang di akhiri dengan judgment. Interpretasi 
dan judgment merupakan tema penilaian yang mengimplikasikan adanya suatu perbandingan antara kriteria dan kenyataan dalam konteks situasi tertentu. Atas dasar itu, maka dalam kegiatan penilaian selalu ada objek atau program, ada kriteria dan ada interpretasi/judgment. Penilaian hasil belajar adalah proses pemberian nilai terhadap hasil-hasil belajar yang di capai siswa dengan kriteria tertentu. Hal ini mengisyaratkan bahwa objek yang di nilainya adalah hasil belajar siswa. Hasil belajar siswa pada hakikatnya adalah perubahan tingkah laku seperti dijelaskan di muka. Tingkah laku sebagai hasil belajar dalam pengertian yang luas mencakup bidang kognitif, afektif dan psikomotorik. Oleh sebab itu dalam penilaian hasil belajar, peranan tujuan intruksional yang berisi rumusan kemampuan dan tingkah laku yang di inginkan di kuasai siswa menjadi unsur penting sebagai dasar dan acuan penilaian. Penilaian proses belajar adalah upaya memberi nilai terhadap kegiatan belajar mengajar yang dilakukan oleh siswa dan guru dalam mencapai tujuan-tujuan pengajaran. Dalam penilaian ini dilihat sejauhmana keefektifan dan keefisienan dalam mencapai tujuan pengajaran atau perubahan tingkah laku siswa. Oleh sebab itu, penilaian hasil dan proses belajar saling berkaitan satu sama lain sebab hasil merupakan akibat dari proses.

Dapat disimpulkan bahwa hasil belajar adalah ukuran untuk mengetahui seberapa jauh seseorang menguasai bahan yang sudah diajarkan. Selain itu hasil belajar juga digunakan untuk mengetahui standar kemampuan anak setelah mendapatkan pembelajaran di kelas sebagai evaluasi pemahaman secara kognitif, afektif dan psikomotor.

Pada sumber lain dijelaskan pula bahwa belajar adalah menguasai atau memperoleh, mengingat-ingat informasi atau keterampilan, melibatkan sistem penyimpanan, memori, dan orgganisasi kognitif, belajar juga melibatkan perhatian aktif sadar padaa, dan bertindak menurut peristiwa di luar serta didalam organisme. (Munggaran, 2010:21)

Pada sumber lain, dijelaskan bahwa "hasil belajar adalah segala sesuatu yang menjadi milik siswa sebagai akibat dari 
kegiatan belajar yang dilakukannya" (Juliah, 2004: 56). Belajar merpakan aspek penting yang menentukan hasil belajar. Oleh sebab itu siswa harus didampingi oleh guru untuk membimbing agar siswa menjadi generasi yang berilmu dan memiliki akhlak yang karimah.

Menurut Hamalik (2003: 89) hasil-hasil belajar adalah pola-pola perbuatan, nilai-nilai, pengertian-pengertian dan sikapsikap, serta apresiasi dan abilitas. Sedangkan menurut Sudjana (2004) berpendapat bahwa "hasil belajar adalah kemampuankemampuan yang dimiliki peserta didik setelah ia menerima pengalaman belajarnya".

Tujuan belajar adalah sejumlah hasil belajar yang menunjukkan bahwa siswa telah melakukan perbuatan belajar, yang pada umumnya meliputi pengetahuan, keterampilan, dan sikap yang baru, yang diharapkan dapat dicapai oleh siswa. (Hamalik, 2013: 183)

Bloom (1956) mengemukakan tiga ranah hasil belajar yaitu kognitif, afektif, dan psikomotor. Untuk aspek kognitif, Bloom menyebutkan 6 tingkatan yaitu pengetahuan, pemahaman, pengertian, aplikasi, analisa, sintesa, dan evaluasi. Berdasarkan uraian tersebut dapat disimpulkan bahwa pada dasarnya proses belajar ditandai dengan adanya peubahan tingkahlaku secara keseluruhan baik yang menyangkut segi kognitif, afektif, maupun psikomotor. Proses perubahan dapat terjadi dari yang paling sederhana sampai pada yang paling kompleks yang bersifat pemecahan masalah, dan peranan kepribadian dalam proses serta hasil belajar. (Sukiyadi, 2006:137)

Ekawarna (2013) dalam bukunya yang berjudul Penelitian Tindakan Kelas mengemukakan bahwa, hasil belajar adalah seluruh kecakapan dan hasil yang dicapai melalui proses belajar mengajar di sekolah yang dinyatakan dengan angka-angka atau nilai-nilai berdasarkan tes hasil belajar. (Ekawarna, 2013: 69). Maksudnya bahwa hasil belajar bukan sebuah penilaian akhir yang harus mengedepankan tidajk hanya aspek kognitif, tetapi juga aspek afektif dan psikomotor. 
Hasil belajar menurut Dick dan Raiser (1989: 7) yang dikutip oleh Ekawarna (2013: 69) adalah kemmpuan-kemampuan yang dimiliki siswa sebagai hasil kegiatan pembelajaran, yang terdiri atas empat macam yaitu pengetahuan, keterampilan intelektual, keterampilan motorik dan sikap.

Pada sumber lain, Arikunto (1990: 102) menyatakan bahwa hasil belajar belajar adalah suatu hasil yang diperoleh siswa setelah mengikuti proses pengajaran yang dilakukan oleh guru. Hasil belajar ini biasanya dinyatakan dalam bentuk angka, huruf, atau kata-kata.

Begitu pula menurut Hamalik (2003: 155) hasil belajar adalah perubahan tingkah laku pada diri siswa, yang dapat diamati dan diukur dalam bentuk perubahan pengetahuan, sikap, dan keterampilan. Selanjutnya Gagne dan Driscoll (1988) dikutip oleh Ekawana (2013: 70) menyatakan bahwa:

Hasil belajar bukan merupakan proses tunggal, melainkan proses yang luas dan dibentuk oleh pertumbuhan dan perkembangan tingkah laku, dimana tingkahlaku tersebut merupakan hasil dari efek kumulatif dari belajar. Artinya, banyak keterampilan yang telah dipelajari memberikan sumbangan bagi belajar keterampilan yang lebih rumit.

Menurut Kingsley (1999) dikutip oleh Jasman Jalil pada bukunya yang berjudul Penelitian Tindakan Kelas, menyatakan bahwa:

Ada tiga macam hasil belajar, yaitu keterampilan dan kebiasaan, pengetahuan dan pengertian, serta sikap dan cita-cita. Tiga hal tersebut pada intinya sama dengan yang diungkapkan pada taksonomi Bloom yakni aspek kognitif, afektif dan psikomotor. Pengetahuan dan pengertian adalah hasil belajar dari aspek kognitif. Keterampilan dan kebiasaan merupakan hasil belajar dari aspek psikomotor. Serta sikap dan cita-cita adalah inti dari aspek afektif. (Jalil, 2014: 79-80). Hubungan tiga macam hasil belajar dengan aktifitas anak dalam menggunakan media social adalah bagaimana anak-anak mencari pengertian, definisi dan informasi pengetahuan baru yang sangat cepat melalui media 
social. Hal ini memebaut anak semakin cepat update informasi terbaru untuk emnambah wawasan disekolah. Oleh sebab itu cara belajar melalui media social dinilai juga berkontribusi terhadap pengetahuan anak-anak.

\section{Pendidikan Agama Islam}

Pelajaran Pendidikan Agama Islam meruuakan materi wajib di SD yang diberikan untuk menanamkan akhlak mulia sejak dini. Mengingat banyaknya tantangan dan pengaruh dari media sosial membuat anak semakin bebas dan lupa waktu.

Pengertian Pendidikan Agama Islam

Pendidikan agama merupakan kata majemuk yang terdiri dari kata "Pendidikan" dan "agama". Dalam kamus umum Bahasa Indonesia, pendidikan berasal dari kata didik, dengan diberi awalan "pe" dan akhiran "an", yang berarti "proses pengubahan sikap dalam usaha mendewasakan manusia melalui upaya pengajaran dan latihan." Sedangkan arti mendidik itu sendiri adalah memelihara dan memberi latihan (ajaran) mengenai akhlak dan kecerdasan pikiran.

Kemudian pengertian Islam itu sendiri adalah agama yang diajarkan oleh Nabi Muhammad SAW berpedoman pada kitab suci Al-Qur'an, yang diturunkan ke dunia melalui wahyu Allah SWT. Agama Islam merupakan sistem tata kehidupan yang pasti bisa menjadikan manusia damai, bahagia, dan sejahtera.

Pengertian Pendidikan Agama Islam sebagaimana yang diungkapkan Zakiyah Daradjat, yaitu:

a. Pendidikan Agama Islam adalah usaha berupa bimbingan dan asuhan terhadap anak didik agar setelah selesai dari pendidikannya dapat memahami dan mengamalkan ajaran agama Islam serta menjadikannya sebagai pandangan hidup (way of life).

b. Pendidikan Agama Islam adalah pendidikan yang dilaksanakan berdasarkan ajaran Islam. c) Pendidikan Agama Islam adalah pendidikan dengan melalui ajaran-ajaran agama 
Islam, yaitu berupa bimbingan dan asuhan terhadap anak didik agar nantinya setelah selesai dari pendidikan ia dapat memahami, menghayati, dan mengamalkan ajaran agama Islam yang telah diyakini menyeluruh, serta menjadikan keselamatan hidup di dunia dan di akhirat kelak.

Sedangkan M. Arifin mendefinisikan pendidikan Agama Islam adalah proses yang mengarahkan manusia kepada kehidupan yang lebih baik dan yang mengangkat derajat kemanusiaannya, sesuai dengan kemampuan dasar (fitrah) dan kemampuan ajarannya (pengaruh dari luar).

Jadi Pendidikan Agama Islam adalah usaha yang berupa pengajaran, bimbingan dan asuhan terhadap anak agar kelak selesai pendidikannya dapat memahami, menghayati, dan mengamalkan agama Islam, serta menjadikannya sebagai jalan kehidupan, baik pribadi maupun kehidupan masyarakat. ${ }^{5}$

Berdasarkan rumusan-rumusan di atas, dapat diambil suatu pengertian, bahwa pendidikan agama Islam merupakan sarana untuk membentuk kepribadian yang utama yang mampu mengamalkan ajaran Islam dalam kehidupan seharihari sesuai dengan norma dan ukuran Islam.

Pendidikan ini harus mampu membimbing, mendidik dan mengajarkan ajaran-ajaran Islam terhadap murid baik mengenai jasmani maupun rohaninya, agar jasmani dan rohani, berkembang dan tumbuh secara selaras.pemberian mainan kepada anak tidak harus diberikan gadget, tetapi masih ada banyak permainan yang lain sesuai dengan tumbuh kembang anak.

\section{Pengaruh Media social Facebook terhadap Hasil Belajar Mata pelajaran PAI}

Sejak munculnya Media social facebook menjadi trend bagi siswa di sekolah dan umum. Facebook menjadi paling diminati oleh masyarakat dunia karena dinilai memiliki featurs yang lebih lengkap dari pada media social lainnya. Manfaat penggunaan facebook juga sangat mewakili ekspresi tidak 
hanay anak muda tetapi juga anak sekolah dasar untuk mengekspresikan dan membangun identitas mereka. Hal yang paling utama dari penggunaan facebook adalah sangat mudah mengoperasikannya dan sangat efisien. Walaupun demikian penggunaan facebook membawa dampak bagi peserta didik khususnya siswa Sekolah Dasar. Hal ini dapat dilihat dari banyaknya kasus permasalahan psikologis, prestasi, bahkan sampai pada hasil belajar anak yang mengalami penurunan yang drastik akibat dari penggunaan facebook. Dengan kata lain penggunaan facebook dapat menyebabkan dekradasi moral anak karena kecanduan medsos dan mengalami dekradasi hasil belajar di sekolah. Dimana anak seharusnya focus belajar dan belajar bersosial, tetapi mereka malah asyik dengan permainan facebook yang sangat menyita waktu belajar yang berdampak pada hasil bekajar dan kecanduan yang berkahir dengan sikap individual anak.

Tinggi antusias siswa dalam menggunakan media social facebook siswa Sekolah Dasar, siswa SDN 3 Tanjungkerta, rata-rata mereka tertarik bermula dari penasaran apa itu Facebook. Kemudian mereka meminta sekali dua kali diajari oleh teman sebaya mereka. Dan pada akhirnya mereka keasyikan menggunakan facebook sehingga mereka larut dalam waktu dan tidak ada semangat untuk belajar. Hal ini tentunya berdampak pada hasil belajar mereka. Oleh sebab itu pengaruh penggunaan facebook terhadap hasil belajar siswa baik secar kognitif, afektif dan psikomotor antara lain;

Secara kognitif

Penggunaan media social facebook tidak lepas dari pengaruh kepada aspek kognitif penggunanya, apalagi terhadap anak-anak Sekolah Dasar. Keseringan menggunakan Facebook tentu membaut pilkiran menajdi lepas tanpa beban. Tetapi hal itu juga berdampak pada hilangnya konsentrasi dan terlenan oleh keadaan yang lepas. Sehingga menjadi lalai dalam mengerjakan sesuatu. Kondisi ini harus diwaspadai terupama untuk anak-anak yang masih labil dan 
memebutuhkan bimbingan dari orang tua ataupun guru di sekolah. Biasanya anak yang sudah kecanduan dengan konten dari facebook akan mudah malas, dan kehilangan daya ingat dan konsentrasi. Dan pada akhirnya anak akan menjadi lemah ingatan.

\section{Secara afektif}

Kecenderungan mengunkan media social facebook memberikan rasa kesenangan dan kecerian, karena telah mengekspresikan emosinya dalam sebuah media social. Media social juga memebantu untuk membangun eksistensi dan hubungan social dengan teman di duania maya yang belum dikenal. Perasaan ini tentunya tidak sepenuhnya senang selamanya. Kesenagan disini hanya bersifat sementara untuk hanya sekedar komen dan share informasi kepada teman. Selain itu eksistensi yang dibangun adalah memeperbanayk pertemanan dan mengenal ornag di dunia luar. Tentunya bukan sebaliknya, media social facebook menjadi pemicu menguatnya sikap acuh tak acuh karena asyik dan terlenan dnegan isi dari facebook.

Secara psikomotor

Penggunaan facebook juga sangat baik terhadap tingkah laku anak karena mereka memiliki aktifitas baru. Mereka bisa mengupload foto, video dan kegiatan hiburan lainnya yang dapat memicu perkembangan psikomotor anak. Maksudnya bahwa anak akan belajar lebih kreatif dan berkreasi dalam dunia maya dengan mengupload aktifitas pribadinya, seperti, olah raga, mengaji, sholat dan lain lain. Walaupun demikian tetap diwaspadai bahwa kebanyakan bermain facebook akan cenderung menjadi malas dan kurang gerak. Sehingga mereka pasif dan berat untuk beraktifitas. 


\section{B. METODE}

Jenis penelitian

Jenis penelitian ini adalah penelitian deskriptif dengan menggunakan pendekatan kuantitatif yaitu, pencarian fakta dengan interprestasi yang tepat. Melalui metode ini diharapkan peneliti dapat memperoleh gambaran secara sistematis, factual, dan akurat mengenai fakta-fakta serta hubungannya dengan masalah yang diteliti. Dan pendekatan yang digunakan dalam penelitian ini adalah kuantitatif yaitu suatu metode penelitian yang berlandaskan pada filsafat postivisme, digunakan untuk meneliti pada populasi atau sampel pada umumnya dilakukan secara random, pengumpulan data menggunakan instrument penelitian analisis yang bersifat kuantitatif/ statistik dengan tujuan untuk menguji hipotesis yang telah ditetapkan (Wawan, 2015:16-17).

Metode penelitian kuantitatif yaitu suatu metode penelitian yang memusatkan diri pada pemecahan masalah-masalah yang ada pada masa sekarang dan bersifat aktual. Metode ini tidak terbatas hanya sampai pada pengumpulan penyusunan data, tetapi meliputi analisa dan interpretasi tentang arti data tersebut. Oleh sebab itu terjadilah sebuah penelitian deskriptif menjelaskan pengaruh media social facebook terhadap hasil belajar mata pelajaran PAI, dengan pengambilan data melalui penyebaran angket kepada siswa kelas VI dan interview kepada guru bagaimana hasil belajar siswa mata pelajaran PAI di kelas.

Lokasi penelitian

a. Tempat Penelitian

Penelitian ini dilaksanakan di SDN 3 Tanjungkerta Kecamatan Pagerageung Kabupaten Tasikmalaya

b. Waktu Penelitian

Waktu penelitian akan dilaksanakan pada tahun ajaran baru 2019/2020 semester ganjil serta disesuaikan dengan jadwal pelajaran. 


\section{Definisi Operasional Variabel}

Untuk memperjelas arah penelitian dan juga menghindari salah penafsiran dan memahami judul penelitian ini, maka perlu adanya definisi operasional terhadap beberapa istilah penting yang digunakan sebagai berikut:

(a) Media sosial facebook merupakan salah satu media komunikasi untuk menjalin pertemanan dan mendeskripsikan diri yang berisi foto, video.

(b) Hasil belajar

hasil belajar adalah kemampuan-kemampuan yang dimiliki peserta didik setelah ia menerima pengalaman belajarnya.

Untuk memperjelas hal tersebut, maka penulis melampirkan tabel.

\section{Populasi, Teknik Sampling, dan Sampel}

Populasi adalah wilayah keseluruhan yang terdiri dari objek/subjek yang mempunyai kualitas dan karakteristik tertentu yang ditetapkan oleh penelitian untuk dipelajari dan kemudian ditarik simpulannya (Sugiyono, $2016: 148$ ). "Populasi adalah keseluruhan subjek penelitian (Wawan Kusnawan, 2007 : 28 )”. Dalam penelitian ini Populasi dalam penelitian ini adalah peserta didik kelas IV SDN 3 Tanjungkerta Kecamatan Pagerageung Kabupaten Tasikmalaya tahun ajaran 2019/2020. Jumlah peserta didik kelas VI menurut data statistik di sekolah tersebut berjumlah 22 orang 100 siswa. Jumlah ini diambil dan dianggap memenuhi syarat penelitian $15 \%$ dari jumlah seluruhnya. Selain itu siswa kelas VI memiliki akun media social facebook dan aktif menggunakannya.

1) Teknik sampling dan sampel penelitian.

Teknik sampling adalah teknik pengambilan sampel dari sebuah populasi. Untuk menentukan sampel dalam penelitian terdapat berbagai teknik sampling yang digunakan.

Dalam penelitian ini teknik sampling yang digunakan adalah purposive sampling. Menurut Wawan (2015:132) menyatakan bahwa "purposive sampling adalah teknik 
penentuan sampel dengan pertimbanan tertentu." Alasan peneliti menggunakan purposive sampling karena peneliti mengharapkan kriteria sampel yang diperoleh benar-benar sesuai dengan penelitian yang akan dilakukan. Dalam hal ini sampling dimaksudkan kepada siswa kelas VI dengan alasan mereka aktif menggunakan facebook.

. Teknik purposive sampling juga digunakan karena peneliti menemukan masalah yang sesuai dengan judul yang di ambil oleh peneliti terjadi dikelas VI. Masalahnya yaitu sebagiaan besar pengguna facebook adalah kelas VI dan hasil belajar siswa PAI menunjukkan hasil yang normal atau hasil belajar PAI siswa masih tergolong cukup.

2) Sampel

Menurut Sugiyono ( $2016: 149$ ) mengatakan bahwa sampel adalah bagian dari jumlah dan karakteristik yang dimiliki oleh populasi tersebut.

Adapun sampel yang digunakan dalam penelitian ini adalah siswa kelas VI SDN 3 Tanjungkerta Kecamatan Pagerageung Kabupaten Tasikmalaya yang berjumlah 22 orang.

\section{Instrumen Penelitian}

Hal yang penting dalam penelitian ialah menentukan instrumen penelitian yang digunakan untuk mengukur variabel. Instrumen penelitian ini menggunakan:

1. Pedoman Observasi

Observasi merupakan pengamatan secara inten yang dilakukan oleh peneliti sebagai instrument utama yang digunakan di lapangan. Proses observasi adalah suatu aktivitas penting mengamati penggunaan facebook yang dilakukan oleh siswa kelas VI setiap hari baik di sekolah maupun di rumah. Pengamatan ini dilakukan berulang ulang agar data yang didapat akurat. 
Moh Saeful Ulum. Muhammad Al Ghiffarie Tsaronny | Pengaruh Penggunaan Media...

2. Pedoman Angket

Angket atau kuesioner merupakan teknik pengumpulan data yang dilakukan dengan cara memberi seperangkat pernyataan atau pertanyaan tertulis kepada responden untuk dijawabnya. Siswa kelas VI sebagai responden untuk mengisi dan menjawab pertanyaan di angket.

3. Pedoman Wawancara

Menurut Denzin dalam Wiriaatmadja ( $2014: 117$ ) wawancara merupakan pertanyaan-pertanyaan yang diajukan secara verbal kepada orang-orang yang dianggap dapat memberikan informasi atau penjelasan hal-hal yang dianggap perlu. Penulis lakukan secara langsung kepada pihak-pihak yang bersangkutan di sekolah.

Sedangkan menurut Hopkins dalam Wiriaatmadja ( 2014 : 117 ) mengatakan bahwa wawancara adalah suatu cara untuk mengetahui situasi tertentu di dalam kelas dilihat dari sudut pandang yang lain. Orang-orang yang di wawancarai dapat termasuk beberapa orang siswa kelas VI, guru PAI dan kepala sekolah.

\section{Teknik Pengumpulan Data}

Teknik untuk menentukan data yang diperlukan maka dibutuhkan adanya teknik pengumpulan data agar bukti-bukti dan fakta yang diperoleh berfungsi sebagai data obyektif sehingga tidak terjadi penyimpangan dari keadaan yang sebenarnya. Adapun teknik pengumpulan data yang digunakan adalah:

\section{Observasi}

Observasi yaitu pengamatan terhadap gejala atau penomena yang diteliti dengan menggunakan alat tertentu, baik dalam situasi yang sebenarnya maupundalam situasi buatan. Dalam penelitian ini peneliti melakukan pengamatan secara langsung terhadap fenomena yang diteliti dengan cara terpimpin.

2. Angket (kuesioner)

Kuesioner merupakan teknik pengumpulan data yang dilakukan dengan cara memberi seperangkat 
pertanyaan atau pertanyaan tertulis kepada responden untuk dijawabnya. Kuesioner merupakan teknik pengumpulan data yang efisien bila peneliti mengetahui dengan pasti variabel yang akan diukur dan mengetahui apa yang bisa diharapkan dari responden. Kuesioner dalam penelitian ini pertanyaan-pertanyaan yang terdiri dari 20 soal pilihan ganda kepada siswa kelas VI SDN 3 Tanjungkerta. Kuisioner diberikan untuk mencari data variable X. Sedangkan untuk mencari data variable Y diambil dari nilai raport mata pelajaran PAI kelas siswa kelas VI pada semester genap tahun 2018/2019.

\section{Prestasi Belajar Fiqih Peserta Didik MTs Negeri} Banjarangsana Kecamatan Panumbangan Kabupaten Ciamis

Berdasarkan hasil uji analisis diperoleh rata-rata hitung untuk prestasi belajar fiqih peserta didik sebesar 77,59, berada pada skala penafsiran diatas 76 dengan klasifikasi kurang. Dapat dijelaskan bahwa prestasi belajar fiqih peserta didik di MTs Negeri Banjarangsana Desa Banjarangsana Kecamatan Panumbangan Kabupaten Ciamis berada pada kriteria kurang.

Hasil penelitian ini menjelaskan bahwa untuk mencapai prestasi belajar, seyogyanya seorang peserta didik mampu membangkitkan faktor-faktor pendukung pencapaian prestasi belajar. Sebab tanpa adanya faktor dalam belajar peserta didik tidak mungkin dapat memahami materi yang disampaikan pendidik dalam setiap proses pembelajaran. Kemudian untuk menjamin belajar yang lebih baik maka peserta didik harus mempunyai perhatian terhadap bahan yang dipelajarinya. Jika bahan pelajaran tidak menjadi perhatian peserta didik, maka timbulah kebosanan sehingga ia tidak lagi suka belajar. Agar peserta didik belajar dengan baik usahakan buku pelajaran itu sesuai dengan hobi dan bakatnya.

Sejalan dengan hasil analisis data, dapat diterangkan bahwa prestasi merupakan salah satu faktor yang dapat mempengaruhi usaha yang dilakukan seseorang. Prestasi yang kuat akan menimbulkan usaha yang gigih serius dan tidak 
mudah putus asa dalam menghadapi tantangan. Jika seorang peserta didik memiliki rasa ingin belajar, ia akan cepat dapat mengerti dan mengingatnya. Seperti yang diungkapkan Abdul Wahid (1998:110-120) bahwa :

1) Prestasi mempengaruhi bentuk intensitas cita-cita. 2) Prestasi sebagai tenaga pendorong yang kuat. 3) Prestasi selalu dipengaruhi oleh jenis dan intensitas. 4) Prestasi yang terbentuk sejak kecil/masa kanak-kanak sering terbawa seumur hidup karena prestasi membawa kepuasan.

Lain halnya dengan prestasi belajar peserta didik yaitu kecenderungan untuk lebih mengikuti proses pembelajaran di ruang kelas. Prestasi dalam hal ini berfungsi sebagai pendorong banyak sedikitnya kesadaran yang menyertai sesuatu aktivitas yang dilakukan. Aktivitas yang disertai dengan prestasi atau dalam kaitannya dengan indicator prestasi yaitu perhatian yang intensif maka peserta didik dalam belajar akan lebih sukses dan prestasinya pun akan lebih tinggi. Maka dari itu sebagai seorang guru harus selalu berusaha untuk mengarahkan bahwa apapun bentuk interaksi yang dilaksanakan peserta didik akan berpengaruh pada proses peningkatan prestasi belajar di kelas.

3. Pengamalan Ibadah Mahdhah Peserta Didik MTs Negeri Banjarangsana Kecamatan Panumbangan Kabupaten Ciamis

Berdasarkah hasil analisis data, dapaat dijelaskan bahwa rata-rata hitung mengenai pengamalan ibadah Mahdhah sebesar 31,63 maka menurut kriteria perhitungan termasuk kurang, berada pada klasifikasi penafsiran di atas 30,01 katagori kurang. Hal ini dapat disimpulkan, bahwa pengamalan ibadah Mahdhah peserta didik kelas VIII MTs Negeri Kecamatan Panumbangan Kabupaten Ciamis tergolong kurang ditinjau dari aspek kontuinitas, sungguh-sungguh dan semangat.

Kaitannya dengan hal tersebut pengamalan ibadah mahdhah peserta didik merupakan bentuk pelaksanaan 
ibadahnya yang seharusnya dilaksanakan setiap hari, setiap waktu. Pengamalan ibadah mahdhah yang dilakukan peserta didik tersebut akan dilihat dan dikritisi oleh dirinya sendiri. Hal ini akan menimbulkan persepsi dirinya sendiri, persepsi yang baik akan memberikan motivasi peserta didik untuk belajar dan mengikuti apa yang dilakukan hatinya sehingga akan berdampak pada meningkatnya prestasi psikomotorik siswa pada materi fikih.

4. Pengaruh Prestasi Belajar Fiqih terhadap Pengamalan Ibadah Mahdhah Peserta Didik MTs Negeri Banjarangsana Kecamatan Panumbangan Kabupaten Ciamis

Hasil penelitian dapat dijabarkan bahwa pengaruh prestasi belajar terhadap pengamalan ibadah berada pada korelasi tinggi dengan nilai sebesar 0,63 dengan hasil determinasi sebesar 39,69\%, pengaruh tersebut signifikan dengan diperolehnya nilai $t_{\text {hitung }}=3627$ sedangkan $t_{\text {tabel }}=1,725$ sehingga Ha diterima dan Ho ditolak. Dengan demikian dapat dinyatakan bahwa "Semakin baik prestasi belajar fiqih maka semakin baik pula pengamalan ibadah mahdhah peserta didik MTs Negeri Banjarangsana Panumbangan Kabupaten Ciamis.

Berdasarkan perhitungan tersebut, didapatkan bahwa hipotesis diterima. Karena pada variabel (x) yaitu prestasi belajar fiqih terpokus pemahaman materi fiqih. Pemahaman merupakan hasil belajar ranah kognitif. Ranah kognitif hanya terpatok pada penerimaan pengetahuan dan penguasaan intelektual semata. Selain pemahaman, satu tingkat kebawah terdapat aspek pengetahuan. Satu tingkat ke atas terdapat analisis, sintesis dan evaluasi.

Dari kelima aspek tersebut merupakan aktivitas berfikir yang masih abstrak dan belum terwujud menjadi sikap dan perilaku nyata dalam kehidupan sehari- hari. Apalagi variabel (Y) merupakan pengamalan Ibadah mahdhah diukur dari hasil pelaksanaanya sehari-hari belum tentu dilaksanakan dengan sebenarnya. Wawancara 
Moh Saeful Ulum, Muhammad Al Ghiffarie Tsaronny I Pengaruh Penggunaan Media...

Wawancara untuk memperoleh pendapat atau pandangan yang dilakukan secara tidak terstruktur, dimana telah disiapkan beberapa pertanyaan tertulis terhadap guru atau kepala sekolah mengenai keadaan sesuai masalah yang diteliti di sekolah.

\section{HASIL DAN PEMBAHASAN}

\section{Analisis Data dan Hasil Penelitian}

a.Penyajian Data Penelitian

Dari hasil angket yang telah disebarkan kepada 22 responden untuk Penggunaan Facebook (sebagai variabel X) dan Hasil belajar Peserta Didik (sebagai variabel Y) yaitu Penggunaan Media Sosial Facebook terhadap hasil belajar peserta Didik Pada Mata Pelajaran Pendidikan Agama Islam di Kelas VI SD Negeri 3 Tanjungkerta, Adapun data dan daftar nama peserta didik yang dijadikan sampel sebanyak 22 siswa kelas VI.

\section{b.Pengolahan Data Penelitian}

1) Menganalis Data Variabel X (Penggunaan Facebook)

a) Skoring data dari angket penelitian

Tabel 4.6

Hasil Skoring Angket Variabel X (Penggunaan

Facebook)

\begin{tabular}{|c|c|c|c|c|c|c|c|c|c|c|c|c|c|c|c|c|c|c|c|c|c|}
\hline \multirow[t]{2}{*}{ No } & \multicolumn{20}{|c|}{ Item Soal } & \multirow[t]{2}{*}{ Skor } \\
\hline & 1 & 2 & 3 & 4 & 5 & 6 & 7 & 8 & 9 & 10 & 11 & 12 & 13 & 14 & 15 & 16 & 17 & 18 & 19 & 20 & \\
\hline 1 & 4 & 5 & 4 & 4 & 5 & 3 & 2 & 2 & 4 & 3 & 2 & 1 & 4 & 4 & 4 & 4 & 4 & 5 & 4 & 4 & 72 \\
\hline 2 & 4 & 4 & 4 & 3 & 4 & 5 & 4 & 4 & 4 & 4 & 4 & 2 & 5 & 5 & 4 & 4 & 5 & 4 & 4 & 5 & 82 \\
\hline 3 & 5 & 4 & 4 & 4 & 3 & 3 & 4 & 3 & 3 & 4 & 5 & 3 & 4 & 4 & 5 & 3 & 4 & 4 & 3 & 4 & 75 \\
\hline 4 & 3 & 5 & 4 & 3 & 4 & 4 & 5 & 4 & 3 & 4 & 2 & 2 & 4 & 4 & 5 & 2 & 3 & 4 & 5 & 3 & 73 \\
\hline 5 & 5 & 2 & 2 & 5 & 5 & 4 & 4 & 5 & 5 & 5 & 5 & 1 & 5 & 4 & 5 & 4 & 2 & 5 & 4 & 3 & 80 \\
\hline 6 & 3 & 5 & 4 & 3 & 4 & 5 & 4 & 3 & 4 & 4 & 3 & 2 & 4 & 5 & 4 & 3 & 4 & 4 & 4 & 4 & 76 \\
\hline 7 & 5 & 4 & 4 & 3 & 3 & 4 & 4 & 3 & 3 & 4 & 5 & 3 & 4 & 4 & 5 & 3 & 4 & 4 & 3 & 4 & 76 \\
\hline 8 & 4 & 4 & 4 & 4 & 5 & 4 & 5 & 5 & 4 & 4 & 4 & 2 & 4 & 4 & 5 & 4 & 4 & 4 & 4 & 4 & 82 \\
\hline 9 & 5 & 5 & 4 & 5 & 5 & 4 & 5 & 5 & 5 & 4 & 4 & 1 & 4 & 5 & 5 & 4 & 5 & 5 & 5 & 5 & 90 \\
\hline
\end{tabular}




\begin{tabular}{|l|l|l|l|l|l|l|l|l|l|l|l|l|l|l|l|l|l|l|l|l|l|}
\hline 10 & 5 & 5 & 4 & 5 & 5 & 2 & 5 & 5 & 4 & 4 & 4 & 1 & 5 & 4 & 4 & 4 & 4 & 5 & 5 & 5 & $\mathbf{8 5}$ \\
\hline 11 & 4 & 5 & 4 & 5 & 5 & 2 & 5 & 5 & 4 & 4 & 3 & 1 & 5 & 4 & 4 & 4 & 3 & 5 & 5 & 5 & 82 \\
\hline 12 & 4 & 5 & 3 & 3 & 5 & 4 & 4 & 5 & 4 & 5 & 3 & 1 & 4 & 4 & 4 & 3 & 3 & 4 & 3 & 3 & $\mathbf{7 4}$ \\
\hline 13 & 5 & 5 & 4 & 5 & 5 & 5 & 5 & 5 & 5 & 5 & 4 & 1 & 5 & 5 & 5 & 5 & 5 & 5 & 5 & 5 & $\mathbf{9 4}$ \\
\hline 14 & 4 & 4 & 3 & 3 & 4 & 3 & 5 & 3 & 4 & 4 & 4 & 3 & 3 & 4 & 5 & 4 & 5 & 4 & 3 & 4 & $\mathbf{7 6}$ \\
\hline 15 & 4 & 5 & 4 & 4 & 5 & 3 & 2 & 2 & 4 & 3 & 2 & 1 & 4 & 4 & 4 & 4 & 4 & 5 & 4 & 4 & $\mathbf{7 2}$ \\
\hline 16 & 5 & 4 & 3 & 5 & 5 & 4 & 5 & 5 & 5 & 4 & 4 & 1 & 4 & 5 & 5 & 4 & 5 & 5 & 5 & 5 & 88 \\
\hline 17 & 5 & 4 & 4 & 5 & 4 & 4 & 5 & 3 & 4 & 4 & 4 & 1 & 5 & 4 & 3 & 4 & 4 & 5 & 5 & 5 & 82 \\
\hline 18 & 5 & 5 & 4 & 5 & 5 & 4 & 5 & 5 & 5 & 4 & 4 & 3 & 5 & 5 & 5 & 4 & 5 & 5 & 5 & 5 & $\mathbf{9 3}$ \\
\hline 19 & 4 & 5 & 4 & 5 & 5 & 3 & 4 & 3 & 2 & 5 & 2 & 2 & 4 & 5 & 4 & 4 & 3 & 5 & 4 & 3 & $\mathbf{7 6}$ \\
\hline 20 & 5 & 5 & 2 & 5 & 4 & 4 & 4 & 5 & 5 & 4 & 5 & 1 & 5 & 4 & 3 & 5 & 4 & 5 & 4 & 5 & 84 \\
\hline 21 & 5 & 5 & 3 & 5 & 5 & 4 & 5 & 5 & 5 & 4 & 4 & 1 & 4 & 5 & 5 & 4 & 5 & 5 & 5 & 5 & 89 \\
\hline 22 & 3 & 5 & 4 & 5 & 5 & 2 & 5 & 5 & 4 & 4 & 3 & 1 & 5 & 4 & 4 & 4 & 3 & 5 & 5 & 5 & $\mathbf{8 1}$ \\
\hline
\end{tabular}

b) Menyusun data

$\begin{array}{lllllllll}72 & 72 & 73 & 74 & 75 & 76 & 76 & 76 & 76 \\ 80 & 81 & 82 & 82 & 82 & 82 & 84 & 85 & 88 \\ 89 & 90 & 93 & 94 & & & & & \end{array}$

Dari data di atas, maka diperoleh data terbesar yaitu 94 dan data terkecilnya yaitu 72 .

c) Menghitung rata-rata/mean ( $\mathbf{x})$, dengan rumus:

$\bar{x}$ Quote $=\frac{\sum n x i}{N}$

$\begin{array}{ll}\bar{x} & \frac{1782}{22} \\ \bar{x} & =81,14\end{array}$

$\bar{x}=81,14$

d) Menghitung simpangan rata-rata (SR), dengan rumus:

$$
\begin{aligned}
\mathrm{R} & =\mathrm{H}-\mathrm{L} \\
& =94-72 \\
& =22
\end{aligned}
$$


Moh Saeful Ulum. Muhammad Al Ghiffarie Tsaronny I Pengaruh Penggunaan Media...

Tabel 4.7

Nilai Harga Mutlak |

Variabel X (Penggunaan Facebook)

\begin{tabular}{|c|c|c|c|c|}
\hline No & $\bar{x}^{-}$ & $x^{-}$ & $\bar{x} \mathrm{t}-\overline{\mathrm{x}} \mid$ & $\sum \|^{-}$ \\
\hline 1 & 72 & 81 & $|72-81|$ & 9 \\
\hline 2 & 72 & 81 & $|72-81|$ & 9 \\
\hline 3 & 73 & 81 & $|73-81|$ & 8 \\
\hline 4 & 74 & 81 & $|74-81|$ & 7 \\
\hline 5 & 75 & 81 & $|75-81|$ & 6 \\
\hline 6 & 76 & 81 & $|76-81|$ & 5 \\
\hline 7 & 76 & 81 & $|76-81|$ & 5 \\
\hline 8 & 76 & 81 & $|76-81|$ & 5 \\
\hline 9 & 76 & 81 & $|76-81|$ & 5 \\
\hline 10 & 80 & 81 & $|80-81|$ & 1 \\
\hline 11 & 81 & 81 & $|81-81|$ & 0 \\
\hline 12 & 82 & 81 & $|82-81|$ & 1 \\
\hline 13 & 82 & 81 & $|82-81|$ & 1 \\
\hline 14 & 82 & 81 & $|82-81|$ & 1 \\
\hline 15 & 82 & 81 & $|82-81|$ & 1 \\
\hline 16 & 84 & 81 & $|84-81|$ & 3 \\
\hline 17 & 85 & 81 & $|85-81|$ & 4 \\
\hline 18 & 88 & 81 & $|88-81|$ & 7 \\
\hline 19 & 89 & 81 & $|89-81|$ & 8 \\
\hline 20 & 90 & 81 & $|90-81|$ & 9 \\
\hline 21 & 93 & 81 & $|93-81|$ & 12 \\
\hline 22 & 94 & 81 & $|94-81|$ & 13 \\
\hline \multicolumn{4}{|c|}{ JUMLAH } & 120 \\
\hline
\end{tabular}

Maka simpangan rata-ratanya adalah

$$
\begin{aligned}
& =120: 22 \\
& =5,45
\end{aligned}
$$

e) Membuat skala penafsiran

Skala penafsiran berdasarkan banyaknya option dalam angket, maka sebagai berikut: 


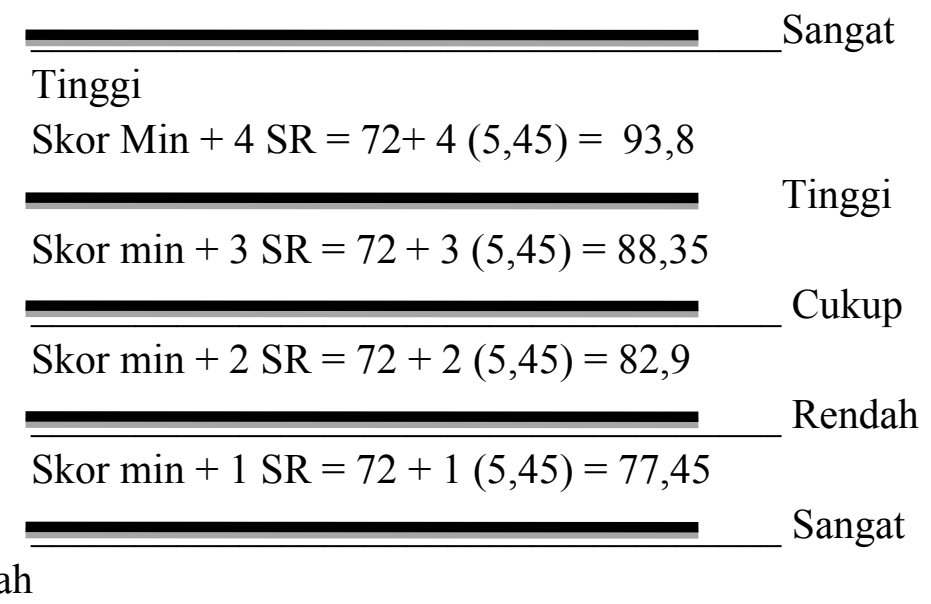

Rendah

Karena untuk variabel X mengenai penggunaan media social facebook adalah 81 maka menurut kriteria perhitungan termasuk baik, karena berada pada skala penafsiran 77,45 - 82,90. Hal ini dapat disimpulkan bahwa penggunaan media social facebook di SD Negeri 3 Tanjungkerta tergolong rendah.

\section{2) Menganalis Data Variabel Y (Hasil Belajar)}

Dengan langkah-langkah sebagai berikut :

a) Skoring data dari Hasil raport siswa mata pelajaran PAI Tahun ajaran 2018/2019

\section{Tabel 4.8}

Hasil Nilai Raport Sampel Kelas VI

Semester Genap Tahun ajaran 2018/2019

Variabel Y (Hasil belajar)

\begin{tabular}{|c|l|c|c|l|}
\hline \multirow{2}{*}{ No. } & \multicolumn{1}{|c|}{ Nama } & \multicolumn{2}{|c|}{ Jenis Kelamin } & \multirow{2}{*}{ Nilai PAI } \\
\cline { 3 - 5 } & & Laki-laki & Perempuan & \\
\hline 1. & Ade Sri Sulistiowati & & V & 77 \\
\hline 2. & Ahmad Fauzan A. & V & & 69 \\
\hline 3. & Dede Jalal & V & & 84 \\
\hline 4. & Devina Septiani & & V & 84 \\
\hline 5. & Dini Amelia & & V & 84 \\
\hline 6. & Euis Karmila & & V & 97 \\
\hline 7. & Ifah Nurkhoiriyah & V & 76 \\
\hline 8. & Insan Muhammad R & & V & 84 \\
\hline 9. & Janiati Rosana W.H. & & 90 \\
\hline
\end{tabular}


Moh Saeful Ulum. Muhammad Al Ghiffarie Tsaronny I Pengaruh Penggunaan Media...

\begin{tabular}{|c|l|c|c|l|}
\hline 10. & Muhamad Rizqi Aziz & V & & 86 \\
\hline 11. & Muhammad As Sahl A.A & V & & 73 \\
\hline 12. & Rahmawati & & V & 78 \\
\hline 13. & Raka Gunawan & V & & 90 \\
\hline 14. & Regiara Macha P. & V & & 75 \\
\hline 15. & Rena Ranpera & & V & 81 \\
\hline 16. & Rohaeni Istiana & & V & 89 \\
\hline 17. & Rosmiati & & V & 83 \\
\hline 18. & Sinta Wati & & V & 74 \\
\hline 19. & Sufia Maulida & & V & 80 \\
\hline 20. & Syifa Nurfadhilah & & V & 86 \\
\hline 21. & Zayid Muhammad S. & V & & 86 \\
\hline 22 & Zayid & V & & 86 \\
\hline Jumlah & & & 1812 \\
\hline
\end{tabular}

b) Menyusun data

$\begin{array}{lllllllll}69 & 73 & 74 & 75 & 76 & 77 & 78 & 80 & 81 \\ 83 & 84 & 84 & 84 & 84 & 86 & 86 & 86 & 86 \\ 89 & 90 & 90 & 97 & & & & & \end{array}$

Dari data di atas, maka diperoleh data terbesar yaitu 97 dan data terkecilnya yaitu 69 .

c) Menghitung rata-rata/mean ( ), dengan rumus:

$$
\begin{aligned}
& \dot{x}=\frac{\sum F i \cdot x i}{\sum F i} \\
& =\frac{1812}{22} \\
& =82,36
\end{aligned}
$$

d) Menghitung simpangan rata-rata (SR), dengan rumus:

Tabel 4.9

Nilai Harga Mutlak |, †

Variabel Y (Hasil Belajar)

\begin{tabular}{|c|c|c|c|c|}
\hline No & $\begin{array}{c}\bar{x}_{\mathrm{t}} \\
-{ }_{\mathrm{t}}\end{array}$ & $-\mathrm{x}$ & $|\mathrm{x}-\mathrm{t}-\overline{\mathrm{x}}|$ & $\sum|\mathrm{x}-\mathrm{t}-\overline{\mathrm{x}}|$ \\
\hline 1 & 69 & 82,36 & $|69-82,36|$ & 13,36 \\
\hline 2 & 73 & 82,36 & $|73-82,36|$ & 9,36 \\
\hline
\end{tabular}


Thorigotuna | Jurnal Pendidikan Islam

\begin{tabular}{|c|c|c|c|c|}
\hline 3 & 74 & 82,36 & $|74-82,36|$ & 8,36 \\
\hline 4 & 75 & 82,36 & $|75-82,36|$ & 7,36 \\
\hline 5 & 76 & 82,36 & $|76-82,36|$ & 6,36 \\
\hline 6 & 77 & 82,36 & $|77-82,36|$ & 5,36 \\
\hline 7 & 78 & 82,36 & $|78-82,36|$ & 4,36 \\
\hline 8 & 80 & 82,36 & $\mid 80-82,36$ & 2,36 \\
\hline 9 & 81 & 82,36 & $|81-82,36|$ & 1,36 \\
\hline 10 & 83 & 82,36 & $|83-82,36|$ & 0,64 \\
\hline 11 & 84 & 82,36 & $|84-82,36|$ & 1,64 \\
\hline 12 & 84 & 82,36 & $|84-82,36|$ & 1,64 \\
\hline 13 & 84 & 82,36 & $|84-82,36|$ & 1,64 \\
\hline 14 & 84 & 82,36 & $|84-82,36|$ & 1,64 \\
\hline 15 & 86 & 82,36 & $|86-82,36|$ & 3,64 \\
\hline 16 & 86 & 82,36 & $|86-82,36|$ & 3,64 \\
\hline 17 & 86 & 82,36 & $|86-82,36|$ & 3,64 \\
\hline 18 & 86 & 82,36 & $|86-82,36|$ & 3,64 \\
\hline 19 & 89 & 82,36 & $|89-82,36|$ & 6,64 \\
\hline 20 & 90 & 82,36 & $|90-82,36|$ & 7,64 \\
\hline 21 & 90 & 82,36 & $|90-82,36|$ & 7,64 \\
\hline 22 & 97 & 82,36 & $|97-82,36|$ & 14,64 \\
\hline & & & & 116,56 \\
\hline
\end{tabular}

Simpangan rata-ratanya adalah

$$
\begin{aligned}
& =116,56: 22 \\
& =5,29
\end{aligned}
$$

e) Membuat skala penafsiran

Skala penafsiran berdasarkan nilai paling rendah dalam raport, maka sebagai berikut:

Sangat Baik

$\begin{array}{ll}\text { Skor Min } & +4(\mathrm{SR}) \\ 69 & +4(5,29) \\ 69 & +21,16=90,16\end{array}$


Moh Saeful Ulum. Muhammad Al Ghiffarie Tsaronny I Pengaruh Penggunaan Mediaw..

Baik

\begin{tabular}{lll} 
Skor Min & $+3(\mathrm{SR})$ & \\
69 & $+3(5,29)$ & \\
69 & $+15,87=84,87$ & \\
& & Cukup \\
\hline Skor Min & $+2(\mathrm{SR})$ & \\
69 & $+2(5,29)$ & \\
69 & $+10,58=79,58$ & \\
& & Rendah \\
\hline Skor Min & $+1(\mathrm{SR})$ & \\
69 & $+1(5,29)$ & \\
69 & $+5,29=74,29$ &
\end{tabular}

Sangat Rendah

Karena untuk variabel Y mengenai hasil belajar peserta didik adalah 82,36, maka menurut kriteria perhitungan termasuk cukup, karena berada pada skala penafsiran 79,58 - 84,87. Hal ini dapat disimpulkan bahwa hasil belajar peserta didik mata pelajaran PAI di SD Negeri 3 Tanjungkerta tergolong cukup.

3) Menganalisis Korelasi antara Variabel $X$ dan Variabel $Y$ dengan langkah-langkah sebagai berikut:

a) Merangking data Variabel X dan Variabel Y

Tabel 4.10

Skor Peringkat Variabel X dan Variabel Y

\begin{tabular}{|c|c|c|c|c|c|c|}
\hline \multirow{2}{*}{ No } & \multicolumn{2}{|c|}{ Skor } & \multicolumn{2}{c|}{ Rangking } & \multirow{2}{*}{ di } & di $^{2}$ \\
\cline { 2 - 5 } & $\mathbf{X}$ & $\mathbf{Y}$ & $\mathbf{X}$ & $\mathbf{Y}$ & & \\
\hline 1 & 72 & 77 & 1,5 & 6 & $-4,5$ & 20,25 \\
\hline 2 & 82 & 69 & 12,25 & 1 & 11,25 & 126,5625 \\
\hline 3 & 75 & 84 & 5 & 11,25 & $-6,25$ & 39,0625 \\
\hline
\end{tabular}




\begin{tabular}{|c|c|c|c|c|c|c|}
\hline 4 & 73 & 84 & 3 & 11,25 & $-8,25$ & 68,0625 \\
\hline 5 & 80 & 84 & 10 & 11,25 & $-1,25$ & 1,5625 \\
\hline 6 & 76 & 74 & 6,25 & 3 & 3,25 & 10,5625 \\
\hline 7 & 76 & 76 & 6,25 & 5 & 1,25 & 1,5625 \\
\hline 8 & 82 & 84 & 12,25 & 11,25 & 1 & 1 \\
\hline 9 & 90 & 90 & 20 & 20,5 & $-0,5$ & 0,25 \\
\hline 10 & 85 & 86 & 17 & 15,25 & 1,75 & 3,0625 \\
\hline 11 & 82 & 73 & 12,25 & 2 & 10,25 & 105,0625 \\
\hline 12 & 74 & 78 & 4 & 7 & -3 & 9 \\
\hline 13 & 94 & 90 & 22 & 20,5 & 1,5 & 2,25 \\
\hline 14 & 76 & 75 & 6,25 & 4 & 2,25 & 5,0625 \\
\hline 15 & 72 & 81 & 1,5 & 9 & $-7,5$ & 56,25 \\
\hline 16 & 88 & 89 & 18 & 19 & -1 & 1 \\
\hline 17 & 82 & 83 & 12,25 & 10 & 2,25 & 5,0625 \\
\hline 18 & 93 & 97 & 21 & 22 & -1 & 1 \\
\hline 19 & 76 & 80 & 6,25 & 8 & $-1,75$ & 3,0625 \\
\hline 20 & 84 & 86 & 16 & 15,25 & 0,75 & 0,5625 \\
\hline 21 & 89 & 86 & 19 & 15,25 & 3,75 & 14,0625 \\
\hline 22 & 81 & 86 & 11 & 15,25 & $-4,25$ & 18,0625 \\
\hline & & JUMLAH & & 492,375 \\
\hline
\end{tabular}

b) Menghitung korelasi antara Variabel X dan Variabel Y, dengan rumus:

$$
\begin{aligned}
\text { rs } & =1-\frac{6 \sum d i^{2}}{N^{3}-N} \\
& =1-\frac{6(492,39)}{22^{3}-22} \\
& =1-\frac{2954,25}{10648} \\
& =1-0,27 \\
& =0,73
\end{aligned}
$$

Membuat skala penafsiran dengan menggunakan klasifikasi guildford tentang batas-batas $\mathrm{P}$ oleh $r s$ dengan ketentuan: 
Moh Saeful Ulum. Muhammad Al Ghiffarie Tsaronny I Pengaruh Penggunaan Media...

$$
\begin{array}{ll}
0,81-1,00 & : \text { Sangat Tinggi } \\
0,61-0,80 & \text { : Tinggi } \\
0,41-0,60 & \text { : Cukup } \\
0,21-0,40 & \text { : Rendah }
\end{array}
$$

Berdasarkan klasifikasi guildford di atas, harga atau nilai $r s$ sebesar 0,73 berada pada klasifikasi sangat tinggi. Hal ini berarti menyatakan bahwa pengaruh penggunaan media social facebook terhadap hasil belajar peserta didik pada mata pelajaran Pendidikan Agama Islam di SD Negeri 3 Tanjungkerta berada pada klasifikasi tinggi.

c) Menguji derajat determinasi, dengan rumus: $\mathrm{d}=r s^{2} \mathrm{X} 100 \%$

$$
\begin{aligned}
& =0,73^{2} \times 100 \% \\
& =0,5329 \\
& d=53,29 \%
\end{aligned}
$$

Berdasarkan hasil perhitungan pengaruh penggunaan media sosial facebook terhadap hasil belajar peserta didik pada mata pelajaran Pendidikan Agama Islam diperoleh nilai 53,29\%. Sedangkan faktor lain yang mempengaruhi hasil belajar peserta didik adalah sebesar 100\% - 53.29\% $=46,71 \%$.

Hasil perhitungan di atas menunjukkan bahwa hasil belajar peserta didik mata pelajaran PAI di SDN 3 Tanjungkerta terpengaruh oleh penggunaan media social facebook sebesar 54\%. Sedangkan faktor lain mencapai $46 \%$. Hal ini menunjukkan bahwa penggunaan media social facebook pengaruhnya sangat tinggi terhadap hasil belajar peserta didik mata pelajaran Pendidikan Agama Islam.

d) Uji signifikasi atau hipotesis korelasi

Uji hipotesis digunakan untuk mengetahui angka koefisien yang ditunjukkan perhitugan di atas, tergolong meyakinkan kebenarannya atau tidak. Kriterianya adalah jika $t_{\text {hitung }}$ $\geq t_{\text {tabel }}$ maka $\mathrm{H}_{\mathrm{a}}$ diterima dan $\mathrm{H}_{0}$ ditolak artinya data tergolong memiliki korelasi yang signifikan. Sedangkan jika $t_{\text {hitung }}<t_{\text {tabel }}$ maka $\mathrm{H}_{\mathrm{a}}$ ditolak dan $\mathrm{H}_{0}$ diterima artinya data tergolong memiliki korelasi yang tidak signifikan. 


$$
\begin{aligned}
\mathrm{t}_{\text {hitung }} & =\mathrm{rs} \sqrt{\frac{N-2}{1-r s^{2}}} \\
& =0,73 \sqrt{\frac{22-2}{1-(0,73)^{2}}} \\
& =4,71 \\
& \mathrm{t} \text { tabel }=\mathrm{t}(1-0,05)(n-2) \\
\text { ttabel } & =\mathrm{t}(1-0,05)(22-2) \\
\text { ttabel } & =\mathrm{t}(0,95)(20) \mathrm{t}_{\text {tabel }} \\
= & 1,72
\end{aligned}
$$

Berdasarkan signifikasi $(0,05)$ dan $\mathrm{dk}(\mathrm{n}-2)$ dengan uji dua pihak (two tail test) dan berpedoman pada tabel distribusi t, maka hipotesis yang digunakan adalah:

5. Hipotesis nol $\left(\mathrm{H}_{0}\right)$ diterima jika: thitung $\leq$ ttabel

6. Hipotesis kerja $\left(\mathrm{H}_{\mathrm{a}}\right)$ diterima jika thitung $\geq$ tabel

Hasil perhitungan ternyata $t_{\text {hitung }}$ sebesar 4,71 sedangkan $t_{\text {tabel }}$ sebesar 1,72. Dapat dijelaskan bahwa $t_{\text {hitung }} 4,71 \geq t_{\text {tabel }} 1,72$ sehingga $\mathrm{H}_{\mathrm{a}}$ diterima dan $\mathrm{H}_{0}$ ditolak.

2. Pembahasan

Berdasarkan hasil penelitian yang dilakukan penulis di SD Negeri 3 Tanjungkerta, bahwa penggunaan media social facebook oleh peserta didik memberikan dampak positif terhadap hasil belajar peserta didik sesuai dengan angket yang telah dibagikan kepada sampel yang telah ditentukan. Data selanjutnya diolah dan dianalisis dengan statistik untuk mengetahui pengaruhnya. Dari angket yang disebarkan kepada siswa kelas VI sebanyak 22 orang, didapatkan pada klasifikasi sangat tinggi. Hal ini berarti penggunaan facebook memiliki pengaruh yang sangat tinggi. Faktor yang paling dominan dapat dilihat dalam jawaban angket, dimana mayoritas siswa menjawab selalu. Facebook memberikan kontribusi yang sangat besar terhadap informasi terbaru dan lebih sering digunakan oleh siswa SD. 
Dari hasil wawancara kepada guru Pendidikan Agama Islam, $\mathrm{Hj}$. Dedeh bahwa penggunaan siswa kelas VI SDN 3 Tanjungkerta cenderung lebih menggunakan media social facebook dalam mengekpresikan keinginan mereka baik di dalam dan di luar sekolah. Walaupun demikian mereka hampir terlena atau lalai terhadap tugas yang diberikan oleh guru. Sebaliknya facebook memberikan manfaat yang positif terhadap aktivitas belajar. Mereka menggunakan untuk sering update status dan melihat posting orang lain, terkadang sharing masalah dan pelajaran di sekolah. Sebagian besar siswa kelas IV juga menggunakan Whatsapp untuk komunikasi dengan teman dan orang lain, facebook masih menjadi favorit bagi siswa-siswi karena feature-nya berisi konten gambar, video dan status yang jelas.

Selanjutnya hasil belajar peserta didik mata pelajaran Pendidikan Agama Islam dalam klasisfikasi cukup. Hal tersebut dapat dilihat dalam jawaban angket yang disebarkan kepada 22 siswa. Hasil belajar mata pelajaran PAI mereka, meliputi aspek kognitif, afektif dan psikomotor dapat dilihat dalam ke tiga aspek siswa tersebut sehari-hari di sekolah dan di rumah bahwa mereka mengerjakan sholat, membaca quran, membaca doa dan menengok teman atau guru yang sakit. Berdasarkan dari wawancara dengan guru PAI, bahwa siswa kelas VI memiliki hasil belajar PAI sesuai dengan standar KKM. Mereka cukup bagus dalam mengikuti dan mencapai hasil belajar PAI yang bagus.

Pengaruh penggunaan media social facebook terhadap hasil belajar peserta didik mata pelajaran Pendidikan Agama Islam di SDN 3 Tanjungkerta sangat rendah. Hal ini dibuktikan dari perhitungan uji korelasi dengan menggunakan rumus rank Spearman didapatkan angka 0,73. Hasil uji determinasi penggunaan facebook cukup tinggi mempengaruhi hasil belajar peserta didik mata pelajaran PAI sebesar $54 \%$. Dan $46 \%$ dipengaruhi oleh factor lain, misalnya media, metode dan saranaprasarana. Kemudian mereka juga sering menggunakan facebook 
untuk sharing masalah melalui chating. Hal ini tentunya juga sangat menunjang bahwa facebook juga memeiliki dampak yang bagus terhadap hasil belajar di sekolah.

Selanjutnya $46 \%$ ditentukan oleh faktor lain yaitu, berasal dari sarana prasarana, media pembelajaran, dan metode pembelajaran di kelas. Peran guru dan orang tua juga kemungkinan salah satu faktor yang bisa mempengaruhi hasil belajar peserta didik pada mata pelajaran Pendidikan Agama Islam di sekolah. Setelah dilakukan perhitungan ternyata $t_{\text {hitungsebesar }}$ 4,71 sedangkan $t_{\text {tabel }}$ sebesar 1,27 . Dapat dijelaskan bahwa $t_{\text {hitung }}$ $4,71 \geq t_{\text {tabel }} 1,27$ sehingga $\mathrm{H}_{\mathrm{a}}$ diterima dan $\mathrm{H}_{0}$ ditolak.

Berdasarkan hasil hipotesis alternatif di atas bahwa siswa di SDN 3 Tanjungkerta memiliki semangat belajar yang bagus sehingga mereka tidak terlena oleh dampak negative dari media social facebook. Sebagian besar masyarakat sangat kuatir dengan bahaya kecanduan media social facebook, namun demikian realitas ini sangat berbeda yang terjadi di SDN 3 Tanjungkerta. Para guru mengawasi dan mengarahkan peserta didik agar mengutamakan kewajiban dan tugas sekolah dan menggunakan media social facebook hanya untuk kepentingan yang berkaitan dengan tugas dan kewajiban sekolah, sebaliknya penggunaan facebook justru membuat lupa waktu dan tugas sekolah.

\section{SIMPULAN}

Berdasarkan uraian isi skripsi yang telah dikemukakan di atas, maka dapat disimpulkan sebagai berikut: penggunaan media social facebook oleh siswa kelas VI SDN 3 Tanjungkerta Kecamatan Pagerageung Tasikmalaya termasuk rendah. Sedangkan hasil belajar belajar peserta didik pada mata pelajaran Pendidikan Agama Islam kelas VI SDN 3 Tanjungkerta Kecamatan Pagerageung Kabupaten Tasikmalaya termasuk cukup. Dan pengaruh penggunaan media social facebook terhadap hasil belajar peserta didik pada mata pelajaran PAI oleh kelas VI SDN 3 Tanjungkerta Kecamatan Pagerageung Kabupaten Tasikmalaya berada pada klasifikasi tinggi. 


\section{DAFTAR PUSTAKA}

Faoz, Rusman (2015). Media Pembelajaran Berbasis Sains . Tasikmalaya : Latifah Press

Fathurrohman, Muhammad (2017). Belajar Dan Pembelajaran Modern. Yogyakarta : Gharudawaca

Kasali, Rhenald. (2018). Self Distruption. Jakarta. Mizan

Kompri (2015). Motivasi Pembelajaran Perspektif Guru dan Murid.

Bandung: PT. Remaja Rosdakarya

Mohd, Ainon dan Hassan, Abdullah ( 2011). 11 Teori dan Prinsip Motivasi di Tempat Kerja. Selangor: PTS PROFESSIONAL

Mulyasa, E (2013). Menjadi Guru Profesional. Bandung: PT Remaja Rosdakarya

Oka, Gede Putu Arya (2017). Media dan Multimedia Pembelajaran. Yogyakarta: Deepublish

Pardosi, Mico. (2013). Buku Panduan Facebook. Selaras. Yogyakarta.

Rusman (2015). Belajar Dan Pembelajaran Berorientasi Standar Proses Pendidikan . Jakarta : Kencana

Sardiman (2011). Interaksi Dan Motivasi Belajar Mengajar. Jakarta : Raja Grapindo Persada.

Setiawan, M Andi (2017). Belajar dan Pembelajaran. Ponorogo: Uwais Inspirasi Indonesia

Smaldino, Sharo E. (2011). Intructional Technology And Media For Learning. Jakarta: PRENADAMEDIA GROUP

Suardi, Moh (2014). Belajar Dan Pembelajaran. Yogyakarta : CV Budi Utama

Sudjana (2002). Metode Statistika. Bandung: Tarsito

Sugiyono (2016). Metode penelitian Menejemen. Bandung: Alfabets

Sugiyono (2017). Metode Penelitian Pendidikan Pendekatan Kuantitatif, Kualitatif dan R\&D. Bandung: Alfabets

Suherman (2003). Evaluasi Pembelajaran Matematika. Bandung: UPI Bandung 
Sumiharsono, Rudy dan Hasanah, Hisbiyatul (2017). Media Pembelajaran. Jember : CV PUSTAKA ABADI

Susilana, Rudi dan Riyana, Cepi (2009) Media Pembelajaran . Bandung

CV Wahana Prima

Suyanto, Kasihani K.E (2010). English For Young Learners. Jakarta : Bumi Aksara

Uno, Hamzah B. (2017). Teori Motivasi dan Pengukurannya. Jakarta :

PT. Bumi Aksara

Wawan (2015). Desain Penelitian Kuantitatif. Tasikmalaya: Latifah Press

Wawan (2015). Pengantar statistika pendidikan. Tasikmalaya: CV Latifah

Wiriaatmadja, Rochiati (2014). Metode Penelitian Tindakan Kelas. Bandung: PT REMAJA ROSDAKARYA

Yaumi, Muhammad (2017). Media Dan Teknologi Pembelajaran. Jakarta: PRENADAMEDIA GROUP

Yusuf, Yasin dan Auliya, Umi (2011). Sirkuit Pintar. Jakarta: Visimedia 